\title{
Study on Naphthalene Acetic Acid and Gibberellic Acid on Growth and Quality of Capsicum (Capsicum annum L.) cv. Indra under Shade Net Conditions
}

\author{
Prateek Singh $^{1}$, Devi Singh ${ }^{1}$, Vijay Bahadur ${ }^{1}$ and Deepak Kumar Jaiswal ${ }^{2 *}$ \\ ${ }^{1}$ Department of Horticulture, SHIATS, Allahabad, India \\ ${ }^{2}$ Department of Entomology and Agricultural Zoology, BHU, Varanasi, India \\ *Corresponding author
}

\section{A B S T R A C T}

Keywords

Capsicum, NAA, GA3, Growth,

Quality, Shade net condition.

Article Info

Accepted:

29 May 2017

Available Online:

10 June 2017
The present investigation entitled "Study on naphthalene acetic acid and gibberellic acid on growth and yield of capsicum (Capsicum annum L.) cv. Indra under Shade net condition" was carried out at the vegetable research farm of the Department of Horticulture, Sam Higginbottom Institute of Agriculture, Technology and Sciences (Deemed to-be University), Allahabad during the Rabi season of 2014 - 2015, the experiment was laid out in Randomized Block Design having 9 treatments 3 replications. The experiment revealed that NAA@60 ppm increased plant height, early flowering, number of branches, plant spread, number of flower per plant, shelf life, TSS, With the above result it can be concluded that NAA@60 ppm is very much beneficial for the growth and quality of capsicum.

\section{Introduction}

Vegetables are an important crop in horticulture sector, occupying and area of 9.20 million ha during 2012-13 with a total production of 162.2 million tones and having average productivity of 17.6 tones /ha In fact vegetables constitute about $61 \%$ of horticulture production. Bell pepper (Capsicum annuum L.) belongs to the family Solanaceae under the genus Capsicum (Shoemaker et al., 1995).

The crop is a native of Tropical South America especially Brazil which is thought to be the original home of peppers (Islam et al., 2010). It is also used in salad and soup preparation. It is very rich in vitamins A (180
IU) and vitamin $\mathrm{C}$ than that of tomatoes. From every 100 gram of edible portion of capsicum $24 \mathrm{k}$ cal of energy, 1.3 gram of protein, 4.3 gram of carbohydrate and 0.3 gram of fat is provided.

It has attained a status of high value crop in India in the recent years and occupies a pride place among vegetables in Indian cuisine, because of its delicate taste and pleasant flavor coupled with rich content of ascorbic acid and other vitamins and minerals. The mature-fruits (green,-red and-yellow) of sweet pepper are eaten raw or widely used in stuffing's, baking's, pizza and burger preparations. 


\section{Materials and Methods}

The present investigation entitled "Study on Naphthalene Acetic Acid and Gibberellic Acid on Growth, Yield and Quality of Capsicum (Capsicum annum L.) cv. Indra under shade net Condition" was conducted from October 2014 -May 2015. The experiment was laid out in a Randomized Block Design with 9 treatments and 3 replications at the experimental field of the Department of Horticulture, Sam Higginbottom Institute of Agriculture, Technology and Sciences, Allahabad.

The experimental site is located at a latitude of $20^{\circ}$ and $15^{\circ}$ North and longitude of $60^{\circ}$ East and at an altitude of 98 meters above mean sea level (MSL) and variety selected for research was INDRA (I.A.R.I., New Delhi). Maintaining a spacing of $60 \times 40 \mathrm{~cm}$ for transplanting, for spraying the growth regulator (promoters) solutions were prepared as per the requirement i.e. $1 \mathrm{ml}$ of growth regulator (promoters) in 10 liters of water gives 100ppm, meanwhile solution prepared as per the requirement sprayed at pre bloom and fruit development stage. Five plants recording observations. The recommended package of practices was followed for raising the successful crop. Data on plant growth and quality characters were recorded seven months after transplanting when the plants were fully grown. Treatment $\left(\mathrm{T}_{0}-\right.$ control, $\mathrm{T}_{2}$ - $\mathrm{GA}_{3}$ 60ppm, $\mathrm{T}_{3}-\mathrm{GA}_{3}$ 80ppm, $\mathrm{T}_{4}-\mathrm{GA}_{3}$ 100ppm, $\mathrm{T}_{5}$ - NAA 30ppm, $\mathrm{T}_{6}-\mathrm{NAA} 40 \mathrm{ppm}$, $\mathrm{T}_{7}-\mathrm{NAA60ppm}, \mathrm{T}_{8}-\mathrm{NAA100ppm}, \mathrm{T}_{1}-\mathrm{GA}_{3}$ 30ppm).

\section{Results and Discussion}

\section{Growth and quality parameters}

The outcome of the investigations for plant height $(\mathrm{cm})$, plant spread $(\mathrm{cm})$, no of branches, days to first flowering, no of flower per plant, total soluble solids ( ${ }^{\circ}$ Brix), shelf life (Days) have been presented in table 1. It was revealed that Maximum plant height $(120.59 \mathrm{~cm})$, Maximum plant spread $(92.57 \mathrm{~cm})$, Maximum no of branches (16.05), Minimum number of days to first flowering (32.51), Maximum no of flower per plant (11.83), Maximum total soluble solids $\left(7.83^{\circ}\right.$ Brix), Maximum shelf life (5.71Days) was found to be in treatment $\mathrm{T}_{7}$ (NAA 60ppm).

This treatment was followed by $\mathrm{T}_{5}$ (NAA $30 \mathrm{ppm})$ in case of plant height $(109.38 \mathrm{~cm})$, plant spread $(87.10 \mathrm{~cm})$, no of branches (13.56), no of flower per plant (10.10), total soluble solids $\left(7.67^{\circ} \mathrm{Brix}\right)$, shelf life (4.25Days) was observed for the treatment $T_{5}$ (NAA 30ppm) while the number of days to flowering was found for the treatment $T_{1}$ $\left(\mathrm{GA}_{3} 30 \mathrm{ppm}\right)$. The Minimum reading was recorded for plant spread $(72.60 \mathrm{~cm})$, no of flower per plant (6.36), total soluble solids $\left(7.34^{\circ} \mathrm{Brix}\right)$ for the treatment $\mathrm{T}_{8}$ (NAA 100ppm) while Minimum plant height and Minimum number of branches per plant was recorded for the treatment $\mathrm{T}_{0}$ (Control) and Maximum no of days to first flowering was found to be for $\mathrm{T}_{8}$ (NAA 100ppm) and the shelf life was found to be minimum for the $\mathrm{T}_{4}$ (GA 3 100ppm).

Good quality and growth parameters were attributed to the cultivation of capsicum in naturally ventilated net house and the effect of plant growth promoters. These results are similar to findings of Rana and Singh (2012) for plant height in capsicum.

Singh et al., (2012) for no of branches in capsicum. Kannan et al., (2009) for fisrt flowering in paprika. Shetty and Manohar (2008) for number of flower per plant in capsicum. Pundir et al., (2001) for TSS in tomato. 
Table.1 Effect of different growth regulators on growth and quality parameter of capsicum

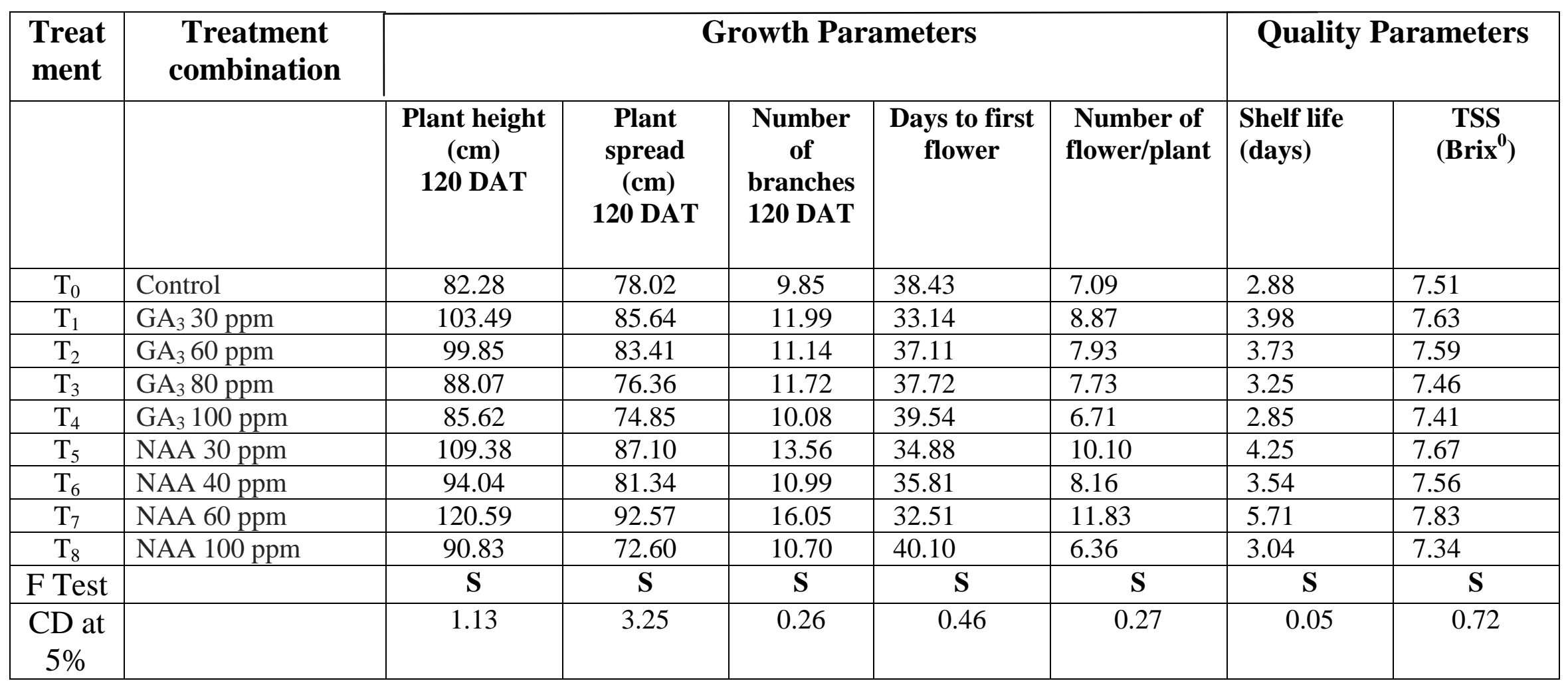


Based on the results obtained in this experiment, it is concluded that the treatment concentration $\mathrm{T}_{7}$ (NAA $60 \mathrm{ppm}$ ) was found to be superior over all other treatments in relation to growth and quality parameters in capsicum under the agro-climatic conditions of Allahabad. However, since these results are based on one year experiment, further trials may be needed to substantiate the results.

\section{Acknowledgement}

Authors wish to acknowledge Dr. Devi Singh, Assistant Professor, Department of Horticulture, Sam Higginbottom Institute of Agriculture, Technology and Sciences, Allahabad and Dr. V. M. Prasad, Professor and head, Sam Higginbottom Institute of Agriculture, Technology and Sciences, Allahabad for their support to carry out this work.

\section{References}

Islam, M., Saha, S., Akand, and Rahim, A, (2010). Effect of sowing date on the growth and yield of sweet pepper (Capsicum annuum L.) Agronomski Glasnik.

Kannan, K., Jawaharlal, M. and Prabhu, M., (2009). Effect of plant growth regulators on growth and yield parameters of paprika cv.ktpl-19. Agriculture Science Digest, 29 (3): 157162.

Pundir, J. P. S. and Yadav, P.K., 1C, (2001). Note on effect of GA3, NAA and 2, 4-D on growth, yield and quality of tomato var, Punjab Chhuhara. Current Agriculture; 25: (1/2): 137-138.

Rana, N.R. and Singh D.K, (2012). Influence of bio regulators on quantitative and qualitative and qualitative parameters of sweet pepper under controlled condition. Progressive Horticulture, 44(1):96-100.

Shoemaker, J. S. and Taskey, B. J. E., (1995). Practical Horticulture, John Wiley and Sons Incorporation, New York.

Shetty G. R, and Manohar, R, K. (2008). Influence of pruning and growth regulators on flowering, fruit set and yield of coloured capsicum (Capsicum annuum L.) cv. Orobelle under naturally ventilated greenhouse. Asian Journal of Horticulture 3(2):213-216.

Singh, R N., Pal, S.L., Rana, D. K., Rawat, S.S. and Gusain, M.S., (2012). Effect of Bioregulators on growth and yield parameter of capsicum cultivars under controlled condition. Hort Flora Research Spectrum 1(1): 50-54.

\section{How to cite this article:}

Prateek Singh, Devi Singh, Vijay Bahadur and Deepak Kumar Jaiswal. 2017. Study on Naphthalene Acetic Acid and Gibberellic Acid on Growth and Quality of Capsicum (Capsicum annum L.) cv. Indra under Shade Net Conditions. Int.J.Curr.Microbiol.App.Sci. 6(6): 25822585. doi: https://doi.org/10.20546/ijcmas.2017.606.307 